\section{Por uma visão dialógica da forma: contribuições do Círculo de Bakhtin para os Estudos da Linguística}

Towards a dialogic view of form: contributions from

Studies

Kelli da Rosa RIBEIRO (ILA-FURG) klro.rib@gmail.com

Recebido em: 02 de jan. de 2018. Aceito em: 24 de jun. de 2018.

RIBEIRO, Kelli da Rosa. Por uma visão dialógica da forma: contribuições do Círculo de Bakhtin para os Estudos da Linguística. Entrepalavras, Fortaleza, v. 8, n. 2, p. 100-119, maio/ago. 2018.

Resumo: Neste artigo, buscamos discutir como as reflexões desenvolvidas pelo Círculo de Bakhtin propõem, ao longo das obras, um estudo da forma linguística numa perspectiva enunciativa e dialógica da linguagem. Por meio de uma investigação qualitativa e bibliográfica, analisaremos como, no conjunto da obra do Círculo, a questão da forma linguística perpassa os diversos conceitos, tais como: sinal e signo, tema e significação, oração e enunciado, gênero do discurso, palavra da língua, palavra-alheia e minha palavra. Discutiremos, portanto, como o pensamento bakhtiniano trata a linguagem em uso, equacionando, em suas formulações, o repetível (dado) e o irrepetível (novo). Com as reflexões levantadas, esperamos ponderar acerca das contribuições do Círculo para a Linguística na contemporaneidade, principalmente no que se refere ao estudo da linguagem nos diferentes usos na sociedade.

Palavras-chave: Forma linguística. Teoria dialógica. Linguística. 
Abstract: In this article, we aim to discuss how the theoretical concepts developed by Bakhtin's Circle propose, over the course of his works, a study of the linguistic form from an enunciative and dialogic perspective of language. Through a qualitative, bibliographic investigation, we will analyze how, in the body of work by the Circle, the issue of the linguistic form permeates the various concepts, such as signal and sign, theme and signifier, clause and utterance, discourse genres, word of a language, an other's word and my word. Therefore, we will discuss how the Bakhtinian line of thinking addresses language in use, focusing, in its formulations, on the repeatable (given) and the unrepeatable (new). With these considerations raised, we hope to examine the contributions of the Circle to contemporary Linguistics, mainly regarding the study of language in its different uses in society.

Keywords: Linguistic form. Dialogic theory. Linguistics.

\section{Introdução}

As concepções teóricas do Círculo de Bakhtin/Volochinov/ Medvedev $^{1}$ têm sido retomadas, mundialmente, por inúmeros pesquisadores da área dos estudos do discurso, devido às grandes contribuições que as pesquisas de gêneros do discurso e outros conceitos desenvolvidos pelos pensadores do Círculo trouxeram e ainda trazem tanto para os estudos da Linguística quanto para os estudos de outros campos das ciências humanas, tais como: Educação, Filosofia, Sociologia etc.

A elaboração teórica do Círculo de Bakhtin, principalmente em Marxismo e filosofia da linguagem [1929], Problemas da poética de Dostoievski [1963], Questões de literatura e de estética: a teoria do romance [1975] e Estética da criação verbal [1979], apresenta alguns questionamentos referentes aos estudos teóricos da época sobre a linguagem. Bakhtin/Volochinov ([1929]2006, p. 74) discorre sobre duas fortes correntes do pensamento linguístico: "o subjetivismo idealista" e o "objetivismo abstrato". Segundo o autor, a primeira orientação interessa-se, sobretudo, "pelo ato da fala, de criação individual como fundamental da língua". Nessa perspectiva teórica, então, o "psiquismo individual constitui a fonte da

\footnotetext{
${ }^{1}$ O Círculo de Bakhtin, postumamente denominado dessa forma pelos estudiosos da área do discurso, era composto por profissionais de diversos campos do conhecimento que tinham ideias em comum. Havia entre o grupo biólogo, pianista, filósofo, professor, entre outros. As ideias essenciais que perpassavam as obras dos estudiosos eram a preocupação com a filosofia e a reflexão sobre a linguagem. É importante destacarmos que os principais nomes representantes das ideias linguísticas do Círculo eram Mikhail Bakhtin, o líder, Valentin Voloshinov e Pavel Medvedev (FARACO, 2009). Em outras reflexões, como em Sériot (2015), no entanto, essa ideia de liderança de Bakhtin no Círculo é questionada. Segundo o autor, essa ideia de liderança pode enfraquecer o papel dos demais membros do Círculo que tinham atuação intensa no grupo e em outros agrupamentos em Leningrado. Bakhtin só utilizou essa expressão nos anos 1970 em entrevista ao especialista em literatura V. Duvakin (SÉRIOT, 2015, p. 29).
} 
V. $8(2)$

100-119

mai/ago 2018

língua", e o olhar do pesquisador se direciona aos fatos da criação verbal individual sem levar em conta a inserção socioideológica do sujeito que produz linguagem (BAKHTIN/VOLOCHINOV, [1929]2006, p. 74).

Já na segunda orientação teórica apresentada pelo autor, no objetivismo abstrato, diferentemente do subjetivismo idealista em que no "fluxo ininterrupto de atos de fala nada conserva sua identidade", são as formas estáveis e repetíveis do sistema que ganham papel central nas pesquisas. O autor ressalta ainda que o "centro organizador de todos os fatos da língua" situa tal orientação com o olhar voltado para o sistema linguístico, isto é, "o sistema das formas fonéticas, gramaticais, e lexicais da língua" (BAKHTIN/VOLOCHINOV, [1929]2006, p. 79).

Em O problema do texto na linguística, na filologia e em outras ciências humanas (BAKHTIN, 2003, p. 313), Bakhtin propõe que o estudo da língua aconteça, levando-se em consideração as singularidades do enunciado e de sua relação dialógica com outros enunciados. Nesse sentido, o filósofo russo afirma que a questão é saber se "a ciência opera com tais individualidades absolutamente singulares como os enunciados" e mais ainda "se eles não iriam além dos limites do conhecimento generalizador" (BAKHTIN, 2003, p. 313).

Assim, compreendemos que a preocupação do Círculo seria, então, pensar um estudo da linguagem que tivesse como foco a interação verbal e que não reduzisse a língua a uma mera ferramenta, descolada de sua realidade social, e, portanto, privada de história e de relações ideológicas. No entanto, para Bakhtin/Volochinov ([1929]2006), as formas são necessárias, pois o locutor, sujeito sócio-historicamente localizado, compartilha de um sistema, por meio do qual todos da comunidade podem lançar mão e, então, delegar um novo sentido à forma utilizada. Na verdade, forma, contexto enunciativo, locutor em relação ao outro estão tão unidos no discurso que, excluindo um ou outro aspecto, corremos o risco de cortar partes importantes em uma análise.

Diante de tais reflexões, surgem as inquietudes que norteiam e motivam a investigação deste texto que tem por objetivo analisar, no conjunto da obra de Bakhtin, o estatuto dado à forma linguística e sua articulação ao sentido concreto do enunciado. Chama-nos a atenção compreender como a forma e o sentido se fundem, levando em consideração uma abordagem dialógica da linguagem. Pensando nessas questões, dividimos nossos apontamentos em dois momentos, seguidos das considerações finais. No primeiro, apresentamos as 
principais noções da teoria dialógica, refletindo sobre os fundamentos do pensamento bakhtiniano. No segundo momento, trazemos à discussão a noção de forma linguística no escopo da teoria dialógica, destacando as contribuições teóricas e metodológicas para os estudos da Linguística.

\section{Teoria dialógica do discurso}

A linguagem, para o Círculo de Bakhtin, é visceralmente dialógica. Tal propriedade não se limita ao diálogo em sua forma composicional nem tampouco como uma forma de resolução de conflitos entre os homens. Na amplitude do raciocínio postulada pela teoria bakhtiniana, a linguagem é vista como um diálogo sem conclusão e inacabável, pois parte de diversas enunciações já ditas no meio social, encontrando o locutor que lhe dará um novo sentido (BAKHTIN/VOLOCHINOV, [1929]2006, p. 98). Por isso, não há limites para o contexto dialógico, assim como não pode haver a primeira nem a última palavra proferida.

Em vista disso, o Círculo, para explicar o princípio dialógico de todo o discurso, ressalta que a palavra, comportando duas faces, procede de alguém e se dirige para alguém. Esse processo acontece em todas as dimensões possíveis da vida da linguagem, pois, como destaca Bakhtin/Volochinov ([1929]2006),

Toda palavra serve de expressão a um em relação ao outro. [...] A palavra é uma espécie de ponte lançada entre mim e os outros. Se ela se apoia sobre mim numa extremidade, na outra apoia-se sobre o meu interlocutor. A palavra é o território comum do locutor e do interlocutor (BAKHTIN/VOLOCHINOV, [1929]2006, p. 17, grifos do autor).

A partir da ideia de "ponte lançada entre mim e os outros", é possível compreendermos que, em qualquer discurso, há uma relação intrínseca de interdependência entre locutor - interlocutor. A palavra como ponte é o lugar do encontro, do confronto, da tensão. Desde uma simples conversa cotidiana em que se fala sobre algo ou alguém, até um texto científico, filosófico ou judiciário apresentarão palavras não inéditas, palavras povoadas já de outras entonações, avaliadas e reavaliadas, enfim, nos discursos, encontramos palavras de outros, dirigidas e projetadas a outros, esperando suas possíveis respostas, arquitetando-se um grande e ininterrupto diálogo.

Através das relações dialógicas inscritas na linguagem, é possível percebermos vozes que penetram os discursos. Para Bakhtin, essas vozes 
V. $8(2)$

100-119

mai/ago 2018

são pontos de vista que se combinam e formam a unidade do discurso, tomado na sua natureza puramente dialógica. As vozes trazem consigo acentuações e valorações que, ao longo da história social da língua, em evolução, se solidificaram e acabaram se vinculando aos discursos dos locutores. Dessa forma, Bakhtin ([1975]1998) salienta que o objeto, ou seja, do que se fala alguma coisa, "está amarrado e penetrado por ideias gerais, por pontos de vista, por apreciações de outros" (BAKHTIN, [1975]1998, p. 86). O discurso, então, orienta-se para seu objeto e "penetra nesse meio dialogicamente tenso de discursos de outrem, de julgamentos e de entonações" (BAKHTIN, [1975]1998, p. 86).

Assim, em Problemas da Poética de Dostoiévski, Bakhtin explica que as relações lógicas (relações entre os elementos fonéticos, lexicais, sintáticos e semânticos) se tornam relações dialógicas no momento em que se materializam, recebendo um autor e sua posição avaliativa. Nesse sentido, ocorrem relações dialógicas entre "enunciações integrais (relativamente)" e ocorrem ainda relações dialógicas entre pontos de vista sobre o objeto do discurso (BAKHTIN, [1963]1999, p. 210).

Com efeito, não podemos deixar de mencionar a relação do dialogismo em Bakhtin com a questão da alteridade. No campo discursivo, o locutor e o interlocutor constroem, cada qual, universo de valores, em que ambos atribuem sentidos às enunciações. A relação de alteridade entre os discursos e os sujeitos caminha ao lado da noção de dialogia, pois não se concebe a produção de linguagem sem a consideração do outro, da resposta ativa do outro. Sobre isso, Bakhtin (2003, p. 379) discorre, dizendo que:

Eu vivo em um mundo de palavras do outro. E toda a minha vida é uma orientação nesse mundo; é reação às palavras do outro [...]. A palavra do outro coloca diante do indivíduo a tarefa especial de compreendê-la [...] o imenso e infinito mundo das palavras do outro são o fato primário da consciência humana e da vida humana... (BAKHTIN, 2003, p. 379).

O autor deixa claro, neste trecho, que a linguagem é essencialmente fruto da inter-relação verbal entre os indivíduos. Além disso, é a partir das incontáveis enunciações alheias que se forma a consciência do sujeito sobre o mundo, a sociedade e a cultura.

Por meio dessa relação com o outro, também criamos a imagem do interlocutor no discurso. Bakhtin, a este respeito, desenvolveu uma importante reflexão em seu texto 0 autor e a personagem na atividade estética (BAKHTIN, 2003) em que a categoria do eu e do outro são 
pressupostas no processo de criação da obra estética. No entanto, para além de leituras especificamente literárias, podemos entender que o autor também se refere às inúmeras produções de discurso e a relação do locutor com sua produção.

O referido texto mostra que só acontece o acabamento da obra estética se houver um distanciamento do sujeito de si mesmo, seguido de um movimento de retorno a si. Bakhtin chama esse processo de excedente de visão estética, salientando que é preciso "entrar em empatia com esse outro indivíduo, ver axiologicamente o mundo de dentro dele tal qual ele o vê, colocar-me no lugar dele [...]" (BAKHTIN, 2003, p. 23). Assim, há a empatia, isto é, a aproximação ao outro e, em seguida, acontece a exotopia, o distanciamento do outro e o retorno a si mesmo. Antes de concretizarmos em enunciados nossas ideias e intenções, levamos em conta nosso destinatário, sua posição avaliativa sobre o mundo e, só depois dessa ação, seja consistente, seja inconscientemente, elaboramos nosso discurso endereçado axiologicamente a outrem.

Precisamos também levar em consideração, ao estudarmos o enunciado, o texto e a linguagem, que é o sujeito o principal agente e produtor de discursos. Quando Bakhtin destaca que os enunciados são respostas, podemos salientar que há sempre, por meio da enunciação, um projeto enunciativo. O enunciado, necessariamente, é a realização concreta do projeto de responder, de (re)significar, de se posicionar.

Se, por um lado, conforme discutimos anteriormente, o enunciado é um evento social que acontece dialogicamente entre os falantes, por outro, não devemos esquecer que há no enunciado traços de algo repetível que o constitui. Atentemos para o que Bakhtin/ Volochinov ([1920/1926]2010, p. 09) afirma em seu texto Discurso na vida e discurso na arte:

O enunciado concreto (e não a abstração linguística) nasce, vive e morre no processo da interação social entre os participantes da enunciação. [...] Quando cortamos o enunciado do solo real que o nutre, perdemos a chave tanto de sua forma quanto de seu conteúdo - tudo que nos resta é uma casca linguística abstrata ou um esquema semântico igualmente abstrato [...]. (BAKHTIN/VOLOCHINOV, [1920/1926]2010, p. 09, grifo nosso).

O autor deixa claro que existe algo que reveste o enunciado. É importante notarmos que era uma preocupação de Bakhtin e de seu Círculo as análises linguísticas exclusivamente formais da época. Na área da Linguística, só as formas abstratas da língua eram levadas em consideração e, na área da Literatura, as análises só atentavam para 
V. $8(2)$

100-119

mai/ago 2018

questões teóricas e formas composicionais da obra. A casca linguística a que o autor se refere, então, só tem vida quando empregada por um falante e enunciada num determinado contexto social. O solo que nutre tal enunciado é justamente a situação discursiva na qual está o enunciado, sendo regado pela multidão de vozes sociais e diferentes axiologias que o fazem ser um todo de sentidos refletidos e refratados (RIBEIRO, 2015). Por isso, o estudo do enunciado necessita da observação das formas linguísticas (sua casca), do sujeito falante e da situação discursiva (solo).

Outra questão que precisa ser levada em conta, na abordagem do enunciado, é seu direcionamento ao outro. Conforme Bakhtin (2003), qualquer enunciado possui um destinatário, sendo mais ou menos próximo ao locutor. Esse destinatário pode ser mais concreto, como, por exemplo, um recado enviado a um amigo ou mais virtual, como, por exemplo, um artigo de opinião de um jornal que tem projetado um determinado tipo de leitor. Assim, entendemos que o locutor do enunciado antecipa e procura dialogicamente o interlocutor a quem dirige seu projeto enunciativo que, aliás, só é de fato um projeto, porque, do seu interlocutor, busca uma atitude de resposta a respeito do que se tratou no discurso, ou seja, o locutor espera a posição avaliativa do interlocutor sobre o objeto do discurso.

Em seu livro Problemas da poética de Dostoievski, no capítulo intitulado O discurso em Dostoievski, Bakhtin aponta diversas reflexões literárias a respeito do discurso dostoievskiano e traz à tona a discussão de conceitos, como discurso, relações dialógicas e palavra. Posicionada sempre na relação eu - outro, a palavra é apresentada como um meio constantemente ativo na cadeia da comunicação dialógica. Além disso, o autor reforça ainda a ideia que perpassa suas reflexões teóricas: a palavra é recebida de outrem repleta de vozes, penetrada por avaliações e julgamentos. Sob este prisma, conclui Bakhtin que a palavra "nunca basta a uma consciência, a uma voz" (BAKHTIN, [1963]1999, p. 203).

Tais vozes sociais que penetram a palavra revelam as mais tensas relações sociais em todos os gêneros e esferas discursivas. Forma-se na palavra um campo de refrações dos eventos sociais, das avaliações já ditas, já contestadas. Por meio das diversas vozes que tocam um signo ideológico, em todas as dimensões das relações dialógicas, sentimos a dupla orientação do discurso, sendo a palavra o território comum do falante e do ouvinte. A palavra é comum ao locutor e ao interlocutor, pois ela tornou-se partilhada socialmente, resultando 
da necessidade de uma ordem, ou seja, de uma organização de falantes em uma determinada comunidade (um país, uma região, por exemplo) para existir a interação entre os envolvidos no processo.

A palavra, nesse contexto, é retirada ainda "quente" da participação sócio-histórica, atravessada por inúmeras entonações, avaliações e se submete ao estilo e a uma "unidade dinâmica" da obra. No entanto, tal processo não é privilégio apenas do gênero romanesco (BAKHTIN, [1975]1998, p. 133). Todo o discurso, em nossas práticas cotidianas, nasce da palavra retirada dos já-ditos, ou seja, palavras entrecruzadas de valores ideológicos, acentos alheios, avaliações sociais das esferas discursivas da comunicação. Por isso, convém distinguirmos, conforme Bakhtin (2003), três aspectos da palavra que se apresentam ao locutor: a palavra da "língua", a palavra "alheia" da palavra "minha". A palavra da "língua" não pertence a ninguém, ou seja, é uma palavra em potencial que ainda não foi entoada por um locutor. A palavra "alheia" pertence aos outros, isto é, vozes de outros, enunciações já proferidas. Por fim, a palavra é considerada "minha" no momento em que o locutor opera com essa palavra e nela insere seu ponto de vista sobre o mundo (BAKHTIN, 2003, p. 293).

Percebemos, nessa discussão, que a palavra como signo ideológico, segundo a visão teórica de Bakhtin e de seu Círculo, se constitui intrinsecamente de elementos estáveis, repetíveis, convencionados socialmente, deixando uma espécie de "espaço" para ser atualizado no contexto discursivo por diferentes locutores em suas situações históricas com valores ideológicos específicos. Além disso, as palavras também refratam a realidade por meio dos diferentes gêneros discursivos.

Sob o prisma da teoria bakhtiniana, todas as atividades e realizações humanas em sociedade estão intrinsecamente relacionadas com a linguagem. A utilização das formas linguísticas se materializa em formas de enunciados ${ }^{2}$ únicos e irrepetíveis realizados por um sujeito sócio-histórico situado em algum campo discursivo da atividade humana. Nesse sentido, Bakhtin elabora o conceito de gênero do discurso, em que é possível observarmos reflexões sobre língua, enunciado e campo discursivo. Assim, o autor destaca que:

\footnotetext{
${ }^{2}$ Na obra de Bakhtin, conforme o tradutor Paulo Bezerra, é possível notarmos que as palavras traduzidas por enunciado e enunciação correspondem a um único termo russo viskázivanie, que pode ser entendido tanto como ato de emissão do discurso quanto um discurso já pronunciado (BAKHTIN, 2003).
} 
V. 8 (2)

$100-119$

mai/ago

2018
Evidentemente, cada enunciado particular é individual, mas cada campo de utilização da língua elabora seus tipos relativamente estáveis de enunciados, os quais denominamos gêneros do discurso. A riqueza e a diversidade dos gêneros do discurso são infinitas porque são inesgotáveis as possibilidades da multiforme atividade humana e porque em cada campo dessa atividade é integral o repertório de gêneros do discurso, que cresce e se diferencia à medida que se desenvolve e se complexifica um determinado campo (BAKHTIN, 2003, p. 262).

É possível compreendermos que os gêneros discursivos surgem e fazem parte da comunicação humana. Os gêneros, além de organizarem os enunciados existentes, são responsáveis por regular/ balizar o funcionamento das diversas ações do homem em sua sociedade. Discutir a noção de gênero, como afirma o próprio filósofo da linguagem, é bastante complexo, já que, de um lado, há o uso da língua que é individual, mas sempre na relação com o outro e, de outro, os enunciados seguem uma repetibilidade própria de cada gênero que é, ao mesmo tempo, dinâmica.

Cabe assinalarmos que, quando Bakhtin se refere à riqueza dos gêneros, está englobando todas as formas de discurso oral e escrito, desde os enunciados de uma simples conversa cotidiana com pessoas íntimas ou diálogos mais formais, como uma entrevista de emprego, até enunciados de documentos oficiais, textos religiosos ou solenidades diversas. O autor chama atenção para a estreita correlação que cada tipo estabelece com a situação de comunicação e como o gênero do discurso cumpre determinada função junto à comunidade falante. Um bom exemplo disso é o anúncio publicitário que surge da necessidade comercial de compra e venda no âmbito social. Embora tal gênero apresente um grau de plasticidade muito grande, identificamos, mediante traços repetíveis, sua característica comercial, que o engendra na esfera do gênero publicitário (RIBEIRO, 2015).

Por meio desse exemplo, é possível compreendermos que o repertório de gêneros discursivos cresce à medida que se complexifica cada campo da atividade humana. Se os gêneros surgem, a partir das necessidades dos sujeitos, surgindo-se novas necessidades, novos gêneros também urgem serem formados. Por exemplo, com o avanço das novas tecnologias e do crescimento na formação de redes sociais no meio digital, surgem novas formas discursivas para atender as necessidades, tais como, editoriais, videoconferências, reportagens ao vivo, bate-papos e até aulas virtuais. Certamente, tais gêneros não surgiram sem uma ancoragem em gêneros anteriores. Marcuschi (2008, 
p. 199) argumenta, por exemplo, o caso do telefonema, "que apresenta similaridade com a conversação que lhe preexiste, mas que, pelo canal telefônico, realiza-se com características próprias".

A discussão sobre os gêneros do discurso, na amplitude postulada pelo Círculo, destaca, como aspecto fundamental de um gênero, o estilo, que está indissoluvelmente ligado à forma composicional do enunciado, bem como ao seu conteúdo temático. Bakhtin (2003, p. 265) afirma que os enunciados refletem as individualidades de cada falante, ou seja, cada sujeito, ao utilizar a língua, deixa, em seu discurso, pistas mais ou menos veladas de sua história e sua visão sobre o mundo. Porém, ressalta o autor que alguns gêneros não são muito propícios a mostrar a individualidade do falante no enunciado, pois a construção composicional própria do gênero não permite tal abertura. Ordens militares e muitas modalidades de discursos oficiais são dados como exemplo por Bakhtin, em seu texto Os gêneros do discurso: o problema e sua definição, para ilustrar formas de enunciados mais padronizados que não abrem muito espaço ao falante e seu estilo.

Já outros gêneros concedem maior liberdade às particularidades dos locutores, como é o caso, por exemplo, de anúncios publicitários, notícias, reportagens, crônicas esportivas etc. Fica evidente, nesse contexto, que a maior elasticidade ou não do gênero está relacionada com a esfera discursiva a qual está filiado. A esfera midiática, esfera discursiva em que se inscreve a publicidade, a notícia, a charge, permite esta abertura, uma vez que trabalha com diversos tipos de produtos, serviços, ideias, dirigindo-se a um vasto e diferente público.

Por fim, destacamos que a questão a ser compreendida, no escopo da teoria dialógica, é como essa concretização das formas acontece na comunicação viva. Trata-se, segundo Clark e Holquist (2008, p. 37), de compreendermos "como as características repetíveis, formais da linguagem são convertidas nos significados não menos formais, mas não-repetíveis das proferições reais". Assim, concluindo juntamente com a visão de Clark e Holquist (2008, p. 37), Bakhtin "procura compreender a complexidade multíplice de elocuções específicas em situações particulares que, considera ele, têm uma sistematicidade diferente, porém não menos ordenada". Entendemos, então, a partir disso, que na enunciação coexistem dois aspectos indissociáveis: o dado (sistema) e o novo (enunciado concreto). 
V. 8 (2)

$100-119$

mai/ago 2018

\section{Estudo dialógico da forma linguística: as obras do Círculo em foco}

Iniciamos esta seção afirmando que, ao longo das obras do Círculo, podemos observar a abordagem dos elementos repetíveis da língua em articulação com o seu uso por sujeitos historicamente situados. A articulação entre forma e uso é considerada por Flores e Teixeira (2009, p. 147) "ponto nevrálgico dos estudos da enunciação" e encontra-se "formulada várias vezes em Bakhtin, mesmo em $\mathrm{MFL}^{3}$, considerada uma obra caracterizada por um antissaussurianismo radical".

O uso de "nevrálgico", pelos autores, é bastante pertinente e explica muito bem a maneira tensa com que Bakhtin/Volochinov desenvolvem o assunto nessa obra. A distinção entre tema e significação realizada no capítulo 7 de Marxismo e Filosofia da Linguagem mostra, evidentemente, esse ponto da tensão, essencialmente, dialógica de uso e forma. Para Flores e Teixeira (2009, p. 147), essa distinção "é indicativa de que o sentido não é reduzido a uma análise puramente contextual, pois há o reconhecimento de um aparato técnico que concorre para sua efetivação".

Também em Marxismo e Filosofia da Linguagem, Bakhtin/ Volochinov, na busca de entender a complexidade da enunciação, fazem a distinção entre sinal e signo, na qual o reiterável (aspecto gramatical) seria o sinal e o mutável seria o signo. Nesse contexto, Faraco (2009, p. 107) considera que "o plano da sinalidade é parte constitutiva do plano da significação do enunciado", ou seja, o sentido do enunciado comportaria duas dimensões inalienáveis: a significação "dada pela estrutura (reiterável e sempre igual)" e a significação "dada pela enunciação (o sempre mutável e adaptável)". Conclui o autor que "o mesmo sinal" passa pelo processo de enunciação e torna-se "outro signo".

No entanto, Bakhtin/Volochinov ([1929]2006, p. 97) asseveram que "a pura sinalidade não existe", ou seja, o uso da forma despida do valor contextual não é possível nem mesmo na fase de aquisição da linguagem pela criança, pois, até neste caso, o uso do sinal é "orientado pelo contexto". Dessa forma, conclui que "o elemento que torna a forma linguística um signo não é sua identidade como sinal, mas sua mobilidade específica", isto é, o sinal torna-se signo no movimento enunciativo sempre novo e irrepetível.

Assim, um mesmo sinal pode transformar-se num signo que circula em diferentes esferas e, nessa circulação, passa a assumir

${ }^{3}$ Abreviação de Marxismo e Filosofia da Linguagem, obra de Bakhtin/Volochinov. 
diferentes sentidos e a refratar diversos valores de um grupo social. A palavra "golpe", por exemplo, no contexto da política brasileira, assume diferentes sentidos de acordo com os locutores que a enunciam. De maneira ampla e genérica, "golpe" pode ter sua sinalidade apontando para significações, como batida, pancada, fissura. Já nos usos específicos, no contexto político brasileiro, tanto em 1964 quanto em 2016, podemos vislumbrar esse signo com sentidos de artimanha, truque, tomada de poder em situações caracterizadas não como golpe, mas como atitudes políticas legitimadas e amparadas por lei.

Faraco (2009, p. 51) explica que os signos têm a capacidade de "apontar uma realidade que lhes é externa", mas isso acontece de maneira refratada. Isto quer dizer que os signos descrevem o mundo (de modo muito generalizado) e, ao mesmo tempo, são construídas diversificadas interpretações e leituras diferentes desse mundo. Ao longo da história de uma sociedade e da sua linguagem, emerge uma heterogeneidade de visões de mundo sobre os objetos, uma vez que "os grupos humanos vão atribuindo valorações diferentes aos entes e eventos, às ações e relações nela ocorrentes" (FARACO, 2009, p. 51).

A palavra é envolvida por valores socioculturais, e tais valores fazem com que essa palavra tenha a condição de um signo ideológico. A palavra, como signo ideológico, acompanha e baliza todos os eventos sociais e ideológicos que acontecem na sociedade. Segundo Ribeiro (2015), o homem vive rodeado pelos signos e acaba criando estes signos para representar os fatos a sua volta, ou seja, por meio dos signos, os falantes tentam interpretar as relações humanas em todas as dimensões possíveis, como, por exemplo, a relação do homem com os fenômenos da natureza, com os animais, com a política, com a ciência, com a religião etc. De acordo com Bakhtin/Volochinov ([1929]2006, p. 35), o signo ideológico só toma existência num "terreno interindividual", ou seja, somente num processo de interação entre duas consciências (dois falantes, no mínimo) é que se torna possível o surgimento de um determinado signo.

As obras do Círculo de Bakhtin também tratam da posição avaliativa no âmbito da palavra, do signo ideológico. Em Marxismo e Filosofia da linguagem, Bakhtin/Volochinov ([1929]2006) fazem uma discussão a respeito das propriedades da palavra. É de tal discussão que partiremos nesta seção. Em MFL, é enfatizado que precisamos considerar que a palavra se constitui de tema e significação. 
V. 8 (2)

100-119

mai/ago 2018
O tema é o sentido da enunciação concreta que acontece sob condições sócio-históricas definidas. Por ser ligado à situação social, é um elemento não reiterável, irrepetível, que não pode ser segmentado em unidades. Já a significação, nessa perspectiva teórica, corresponde aos elementos reiteráveis da língua que são convencionados pela comunidade linguística. Tomando novamente o exemplo da palavra "golpe", é possível observarmos que neste signo há uma significância genérica que é compartilhada socialmente entre os falantes. No entanto, cada vez que essa palavra entra no cenário de contextos diferentes, novos temas se engendram em "golpe". No quadro político brasileiro atual, em que tivemos a retirada da presidenta Dilma Rousseff da presidência da República, há, de um lado, "golpe" com entonações pejorativas advindas de tematizações em contextos favoráveis ao governo que tomou o poder. Normalmente, neste contexto favorável ao governo interino, usamos o signo "impeachment" para designar esse mesmo fato. Teremos, por outro lado, o signo "golpe", sendo tematizado com entonações de protesto, em contextos favoráveis ao governo que foi retirado do poder. De modo geral, nos temas criados para "golpe", no contexto favorável ao governo deposto, circulam vozes de crítica contundente ao fato ocorrido que é designado como impeachment.

A discussão desse exemplo nos permite confirmar a observação de Bakhtin/Volochinov ([1929]2010, p. 140) de que toda enunciação se constrói tendo como base uma "orientação apreciativa". Assim, na enunciação viva e concreta, cada elemento do discurso possui "ao mesmo tempo um sentido e uma apreciação". Percebemos, assim, uma evidente "tríade" de propriedades do signo ideológico em uso: significação (elementos formais da língua), tema (sentido de uma enunciação concreta) e entonação/acento apreciativo (posição tomada pelo sujeito que enuncia). Essa tríade é sustentada pelas relações dialógicas de alteridade e atravessada pela diversidade de vozes sociais que emergem a partir dos signos.

Tratando a palavra de uma maneira viva e concreta, em que propõem tema e significação na composição da palavra, Bakhtin/ Volochinov nos mostram que existe algo mais complexo subjacente à estrutura linguística abstrata, ou seja, algo que dá vida a essa estrutura:

[...] o tema da enunciação é determinado não só pelas formas linguísticas que entram na composição (as palavras, as formas morfológicas ou sintáticas, os sons, as entoações), mas igualmente pelos elementos não verbais da situação. Se perdermos de vista os elementos da situação, estaremos 
tampouco aptos a compreender a enunciação como se perdêssemos suas palavras mais importantes (BAKHTIN/ VOLOCHINOV, [1929]2006, p. 133).

Como a enunciação é um processo complexo e dinâmico, precisamos, então, ponderar que as formas linguísticas são penetradas pela entonação do falante sob uma determinada situação, inscrita num determinado gênero, com um arsenal de valores sociais se entrecruzando continuamente em tal processo.

Dessa forma, podemos compreender que os autores estão preocupados em formular uma reflexão teórica sobre a linguagem que abarque o processo enunciativo em sua globalidade e, conforme Faraco (2009, p. 108), "ele [Bakhtin/Volochinov] não consegue falar do enunciado sem admitir que há nele uma face reiterável". Assim, o que as postulações teóricas do Círculo colocam como cerne na questão da linguagem em uso, segundo Faraco (2009, p. 26), é que "a palavra deve ocorrer em sua inteireza, o que compreende seu aspecto concreto palpável (morfossintático e fonológico), seu aspecto semântico-conceitual e seu aspecto axiológico". É em busca do desenvolvimento dessa reflexão no conjunto das concepções do Círculo que esta discussão se direciona, procurando estabelecer discussões enunciativas não só com Marxismo e Filosofia da Linguagem e Problemas da Poética de Dostoiévski, mas também com as outras obras do Círculo.

Ao se falar nessa articulação da forma linguística ao uso, alguns autores também tecem breves reflexões a respeito da obra Problemas da Poética de Dostoiévski, na qual Bakhtin faz importantes considerações sobre a língua (abstrata) como objeto específico da Linguística e a língua em sua integridade na cadeia da comunicação discursiva. Flores e Teixeira (2009, p. 148) comentam que:

Bakhtin considera legítimo e necessário o procedimento da linguística de recortar o objeto língua pela abstração de alguns aspectos da vida concreta do discurso. No entanto, situa seu interesse exatamente nos aspectos deixados de lado pela linguística, propondo uma segunda disciplina para estudar o discurso, a metalinguística (ou translinguística). Para ele, linguística e metalinguística têm objetos autônomos e metas próprias, ainda que não necessariamente excludentes. A linguística estuda a linguagem na sua generalidade, como algo que torna possível a comunicação dialógica, enquanto a metalinguística ocupa-se do que ele chama de relações dialógicas (FLORES; TEIXEIRA, 2009, p. 148). 
V. 8 (2)

100-119 mai/ago 2018
Destacamos, no trecho dos autores, que a reflexão bakhtiniana é justamente dialógica, isto é, a translinguística, em sua generalidade, leva em consideração aspectos da vida concreta do discurso, e seu recorte é necessário para que se compreenda a própria natureza das relações dialógicas. Faraco (2009, p. 66, grifo do autor) ressalta que, "para haver relações dialógicas, é preciso que qualquer material linguístico tenha entrado na esfera do discurso, tenha sido transformado num enunciado, tenha fixado a posição de um sujeito social." E, nessa direção, concluímos que a condição, para que as relações lógico-semânticas, isto é, as relações no interior do sistema linguístico, se tornem dialógicas é que tais relações deixem de ser propriamente abstratas, materializando-se em discursos vivos e reais.

Partindo, então, das questões levantas pelos autores discutidos, neste espaço, podemos afirmar que o pensamento bakhtiniano construído, em torno da linguagem, ao longo das obras, traz diversas reflexões a respeito da forma linguística abstrata no âmbito das relações dialógicas do enunciado concreto, sendo parte indivisível deste. Além disso, os elementos reiteráveis da língua são abordados pelo Círculo não só em críticas ao objetivismo abstrato, mas tais elementos constituem muitos conceitos importantes e percorrem a grande maioria das obras.

Nessa perspectiva, vale ressaltarmos que este debate também oportuniza a compreensão do desenvolvimento das reflexões em torno da forma linguística como constituinte do sentido, desde as primeiras obras de Bakhtin, como em Para uma filosofia do ato [1920/1926] até um de seus últimos escritos, Apontamentos 1970-1971 [1974]. Assim, acreditamos que é importante mostrarmos, neste espaço, as primeiras ideias sobre os elementos linguísticos em Para uma filosofia do ato e as últimas reflexões de Bakhtin sobre o assunto em Apontamentos 1970-1971, seu penúltimo texto.

Em Para uma filosofia do ato, Bakhtin demonstra preocupação em discutir sobre a estreita relação mantida entre linguagem e ações humanas. Além disso, o autor faz complexas reflexões sobre o Ser-evento e sua responsabilidade no ato estético, ou seja, no ato discursivo, o que ele chama de "não-álibi". Bakhtin, na referida obra, ressalta que a expressão de um ato realizado é "a expressão do Ser-evento único e unitário". O ato é concretizado na plenitude da palavra que tem, segundo o autor russo, três aspectos inseparáveis: o aspecto de seu conteúdo, isto é, "a palavra como conceito"; o aspecto palpável-expressivo, que considera "a palavra como imagem"; e, por fim, seu aspecto emocional-volitivo, ou seja, "a entonação da palavra" (BAKHTIN, [1920;1926]2010, p. 49). 
Partindo dessa reflexão, podemos compreender que o aspecto de conteúdo e de imagem da palavra são aspectos que possuem a forma como constitutiva. O autor pretende discutir justamente sobre a concretude do Ser-evento, da qual o elemento reiterável faz parte, é constitutivo. No entanto, o que concretiza a potencialidade (de significar) desse elemento reiterável é o acento de valor. Percebemos, então, que Bakhtin reconhece a parte formal linguística (conteúdo e expressão da palavra) como parte da inteireza do ato (enunciação) aliada à valoração, aspecto que concretiza a abstração. É por isso que Bakhtin ([1920;1926]2010, p. 49) responde que "a linguagem cresceu a serviço [...] dos atos realizados", no sentido de que também o aparato técnico da língua viabiliza o ato concreto, isto é, os elementos abstratos da língua viabilizam a comunicação, o discurso.

Já em Apontamentos 1970-1971, o sistema linguístico abstrato é alvo de novas reflexões no âmbito discursivo e dialógico. Bakhtin, neste texto, discute sobre várias temáticas que perpassam o conjunto de sua obra, entre essas temáticas destacam-se as relações dialógicas existentes entre os enunciados. O autor pontua que "não pode haver enunciado isolado", isto é, "ele sempre pressupõe enunciados que o antecedem e o sucedem" (BAKHTIN, 2003, p. 371). Aprofundando sua reflexão sobre esse princípio dialógico, inscrito em qualquer enunciado concreto, Bakhtin (2003, p. 374) afirma que existem três tipos de relações: (i) Relações entre os objetos: entre coisas, entre fenômenos físicos, fenômenos químicos; relações causais, relações matemáticas, relações lógicas, relações linguísticas. (ii) Relações entre o sujeito e o objeto; (iii) Relações entre sujeitos: relações pessoais, relações dialógicas entre os enunciados, relações éticas.

Tal divisão de "relações" elaborada por Bakhtin nos permite considerar que, como se tratam de "relações", existe uma interdependência semântica constitutiva entre elas. O terceiro tipo de relação (entre sujeitos), por exemplo, precisa que os sujeitos participantes entrem em relação com o objeto e, sobre esse objeto, por sua vez, pressupomos que ele já tenha estabelecido relações entre si. Discursivamente, nessa perspectiva, o sujeito falante entra em contato com sua língua ( $2^{\circ}$ tipo de relações), que, por si só, já se apresenta a ele com seus elementos relacionados, por meio de sua organização morfológica, sintática e semântica ( $1^{\circ}$ tipo de relações). Tal sujeito, então, está preparado para manter diversas relações sociais e culturais com outros sujeitos falantes ( $3^{\circ}$ tipo de relações). 
V. 8 (2)

100-119 mai/ago 2018

Considerando a complexidade e o lugar da forma nessas relações, no texto o problema do conteúdo, do material e da forma na criação literária, Bakhtin discute acerca da importância da forma e do material para a arquitetônica que envolve o conteúdo na criação estética. Para Bakhtin ([1975]1998), a forma pode ser compreendida em duas direções: a partir do interior do objeto estético puro, como forma arquitetônica, axiologicamente voltada para o conteúdo, e a partir do interior do todo composicional e material da obra. Nesse sentido, o autor ressalta que, com muita frequência, "a forma é compreendida apenas como técnica" e isso reduziria a discussão sobre o ato de criação estética (BAKHTIN, [1975]1998, p. 57). A fim de discutir sobre essa problemática, encontramos no texto de Bakhtin a seguinte questão: "Como a forma, sendo inteiramente realizada no material, torna-se, no entanto, a forma de um conteúdo e relaciona-se axiologicamente com ele?" (BAKHTIN, [1975]1998, p. 57)

Na esteira da complexidade dessa pergunta, há também profundas respostas dadas ao longo da explanação feita por Bakhtin ([1975]1998) em torno da relação forma, material e conteúdo. De acordo com o autor, "na forma eu encontro a mim mesmo, minha atividade produtiva de formalização axiológica" (BAKHTIN, [1975]1998, p. 58). A forma seria, nesse caso, o lugar de encontro do conteúdo e da valoração do locutor. Há, na verdade, uma experimentação da forma como relação axiológica ativa com o conteúdo, para a composição da arquitetônica dessa relação. "É na forma e pela forma que eu canto, narro, represento, por meio da forma eu expresso meu amor, minha certeza, minha adesão" (BAKHTIN, [1975]1998, p. 58).

Diante das reflexões apresentadas, ressaltamos que a avaliação social é parte essencial do processo de estabelecimento de sentidos no signo ideológico. Medviédev ([1928]2012, p. 190) afirma que a entonação "leva-nos além dos limites do enunciado para outra realidade", ou seja, "a palavra é apenas um apêndice de outra presença". Isto significa dizer que as palavras estão necessariamente ligadas ao contexto e aos julgamentos de valor como se fossem apêndices dessa realidade social.

Ao cortarmos a palavra da sua realidade concreta, corremos o risco de isolar seu sentido e reduzi-lo à significação de formas abstratas. É nesse sentido que Volochinov/Bakhtin ([1926]2011, p. 165) destacam que, se a enunciação for arrancada "do chão real que a alimenta", perde-se o acesso de "compreensão tanto de sua forma quanto de seu sentido", restando apenas a "moldura linguística abstrata". Assim, 
entendemos que é necessariamente o uso da linguagem que permite a ultrapassagem da moldura linguística abstrata ao enunciado concreto e vivo na cadeia da comunicação discursiva.

A partir dessa ideia, destacamos que os estudos do Círculo possibilitam às pesquisas que envolvem a linguagem em uso um olhar que analisa o plural, mas não descarta o único, pelo contrário, é um olhar teórico e metodológico para o objeto, situando sua singularidade em meio à diversidade. Na verdade, os sentidos são fixados e compreendidos, quando olhados sob essa ótica dialógica, quando observados na tensão com o outro (RIBEIRO, 2015). No âmbito dos estudos em Linguística Aplicada, tal realidade científica torna-se imprescindível, uma vez que, cada vez mais, buscamos ultrapassar as cisões entre teoria e prática, entre forma linguística e uso. Sem vencer essas barreiras, o estudo da linguagem se fecha em si mesma e cai no abismo da abstração de enunciados sem vida.

Nessa direção, concordamos com Barros (2007) quando revelam que as ideias desenvolvidas pelos estudiosos do Círculo de Bakhtin se constituem como uma revolução epistemológica de grande porte, por se tratarem do estudo das realidades humanas, das relações entre sujeito e sua linguagem e dos diversos discursos que circulam em diferentes esferas e gêneros discursivos (BARROS, 2007, p. 09). Com efeito, destacamos que estudar e aprofundar os conceitos bakhtinianos possibilita o tratamento do singular, do único, do irrepetível na (in) tensa relação com a coletividade das interações socioverbais.

É importante sublinharmos ainda a grande contribuição que a abordagem dialógica da linguagem pode proporcionar às outras áreas das Ciências Humanas. Conforme pontua Amorim (2002, p. 11), os estudos bakhtinianos tornam problemática "toda ilusão de transparência de um texto de pesquisa", isto é, sempre haverá uma "espessura e uma instabilidade que se devem levar em conta e que remetem à própria espessura e instabilidade do objeto e do saber que estão se tecendo no texto". Esse objeto não para nunca de se movimentar e, a cada vez que dele se fala, novos sentidos reverberam para os sujeitos.

\section{Considerações finais}

As ideias bakhtinianas concebem a dialogicidade como elemento constituinte de todo discurso. Consideramos que entre a forma linguística e o sentido do enunciado concreto não há, necessariamente, 
V. 8 (2)

100-119

mai/ago 2018

uma cisão, mas, pelo viés desenvolvido pelo Círculo entre forma e sentido, há uma (inter)relação dialógica e uma complementação mútua. Além disso, as abordagens teóricas de Bakhtin (e do Círculo) são retomadas por várias áreas do conhecimento e a Linguística; em estudos enunciativos da linguagem, tem sido uma das áreas que mais tem relação com o pensamento bakhtiniano.

Nessa perspectiva, como o sistema da língua envolve processos fonológicos, morfológicos, sintáticos e semânticos, é relevante observarmos, por meio de uma teoria filosófica e enunciativa da linguagem, a maneira como esses elementos são engendrados no todo do processo discursivo. Nossas reflexões mostram que, ao se discutir sobre a noção de elementos linguísticos, que perpassam os diversos conceitos da teoria dialógica do discurso, poderá se desfazer incompreensões e banalizações teóricas relacionadas às ideias bakhtinianas feitas ao longo dos anos. Uma dessas incompreensões, por exemplo, se refere à crítica feita ao objetivismo abstrato em Marxismo e Filosofia da Linguagem que muitos interpretam como um antissaussurianismo radical.

Barbisan e Di Fanti (2010, p. 08), nessa direção, afirmam que "o diálogo estabelecido entre o Círculo de Bakhtin e Saussure não se restringiu a uma crítica inconsequente, no sentido de refutar e ignorar as contribuições saussurianas sobre o estudo da língua". Entendemos que o diálogo (tenso) que Bakhtin e o Círculo propõem aos postulados de Saussure constitui a possibilidade, seguindo as palavras de Barbisan e Di Fanti (2010, p. 08), de uma "construção de reflexões referentes à natureza dialógica da enunciação e da linguagem". Portanto, descortinar tal diálogo será a oportunidade de mostrarmos que forma linguística, acento de valor e uso da linguagem são elementos indissociáveis e interdependentes na construção de sentidos na enunciação, ampliando-se, assim, as possibilidades de investigação da área dos estudos do discurso, no interior do campo da Linguística.

\section{Referências}

AMORIM, Marília. Abordagem sócio-histórica na pesquisa qualitativa. Cadernos de Pesquisa, n. 116, p. 7-19, jul. 2002.

BAKHTIN, Mikhail. (VOLOCHINOV, Valentin). Marxismo e Filosofia da linguagem: Problemas fundamentais do método sociológico na ciência da linguagem. (1929). Trad. Michel Lahud e Yara Frateschi Vieira. 12. ed. São Paulo: Hucitec, 2006.

BAKHTIN, Mikhail. Estética da criação verbal [1979]. Trad. Paulo Bezerra. 4. ed. São Paulo: Martins Fontes, 2003. 
Questões de Literatura e de Estética: a teoria do romance [1975]. Trad. Aurora F. Bernardini et. al. 4. ed. São Paulo: Editora da UNESP, Hucitec, 1998.

Problemas da poética de Dostoiévski. [1963]. Trad. Paulo Bezerra. Rio de Janeiro: Forense, 1999.

Para uma filosofia do ato [1920/1924]. Trad. Carlos Alberto Faraco e Valdemir Miotello. São Carlos: Pedro \& João Editores, 2010.

BARBISAN, Leci Borges; DI FANTI, Maria da Glória Corrêa. Estudos da enunciação: bases epistemológicas e perspectivas atuais. Cadernos de pesquisas e linguística, Porto Alegre, v. 5, n. 1, p. 5-25, nov. 2010.

BARROS, Diana Luz Pessoa. Contribuições de Bakhtin às teorias do texto e do discurso. In: FARACO, Carlos Alberto; TEZZA, Cristovão; CASTRO, Gilberto de (Orgs). Diálogos com Bakhtin. Curitiba: Editora UFPR, 2007.

CLARK, Katerina; HOLQUIST, Michael. Mikhail Bakhtin. Trad. J. Guinsburg. São Paulo: Perspectiva, 2008.

FARACO, Carlos Alberto. Linguagem \& diálogo: as ideias linguísticas do círculo de Bakhtin. São Paulo: Parábola Editorial, 2009.

FLORES, Valdir do Nascimento; TEIXEIRA, Marlene. Enunciação, dialogismo, intersubjetividade: um estudo sobre Bakhtin e Benveniste. Bakhtiniana, São Paulo, v. 1, n. 2, p. 143-164, $2^{0}$ sem. 2009.

MARCUSCHI, Luiz Antônio. Produção textual, análise de gêneros e compreensão. São Paulo: Parábola Editorial, 2008.

MEDVIÉDEV, Pavel. o método formal nos estudos literários: introdução crítica a uma poética sociológica. Trad. Sheila Grillo e Ekaterina Américo. São Paulo: Contexto, 2012.

RIBEIRO, Kelli da Rosa. Bivocalização e plurivocalização no culto televisivo show da fé: tensão entre fé, Mercado e publicidade. 2015, 261 f. Tese (Doutorado em Letras) - Pontifícia Universidade Católica do Rio Grande do Sul, Porto Alegre, 2015

SÉRIOT, Patrick. Voloshinov e a filosofia da linguagem. Trad. Marcos Bagno. 1ed. São Paulo: Parábola Editorial, 2015.

VOLOCHINOV, Valentin (BAKHTIN, Mikhail). A palavra na vida e na poesia: introdução ao problema da poética sociológica. In: MIOTELLO, Valdemir (Org.). Palavra própria e palavra outra na sintaxe da enunciação. Trad. Allan Pugliese, Camila Scherma, Carlos Turati, Fabrício Oliveira, Marina Figueiredo, Regina Silva e Valdemir Miotello. São Carlos: Pedro \& João editores, 2011. 